\title{
sciendo
}

\section{BIOSENSORS IN EVALUATION OF QUALITY OF MEAT AND MEAT PRODUCTS - A REVIEW}

\author{
Barbara Sionek, Wiesław Przybylski, Krzysztof Tambor \\ Department of Food Gastronomy and Food Hygiene, Institute of Human Nutrition Sciences, \\ Warsaw University of Life Sciences, Nowoursynowska 159C, 02-776 Warsaw, Poland \\ Corresponding authors: barbara sionek@sggw.edu.pl; \\ wieslaw_przybylski@sggw.edu.pl; krzysztof_tambor@sggw.edu.pl
}

\begin{abstract}
Biosensors can find application in meat and meat products testing for safety, including microbial and other contaminants, and quality, including meat freshness, beef tenderness and pork quality defects. The available biosensors enable the evaluation of freshness, the classification of tenderness of meat products, the evaluation of the glycolysis extent and the presence of the microbial and other contaminants. Since biosensors depend on receptor types, the expansion of knowledge on metabolic transformations occurring in meat contributes to the development of new potential markers and indicators. Examples include assays for glucose, lactates, hypoxanthines, calpastastins, microbial and other contaminants in meat products, augmenting conventional methods. At the same time, biosensors rely on transducers for detection, requiring achievement in many fields including nanotechnology and optics, among others. Biosensors have potential to become a fundamental tool for monitoring and controlling safety and quality of meat products in the future. Hence the aim of the present paper is to present the current state of knowledge on the application of biosensors in meat.
\end{abstract}

Key words: biosensors, meat safety, meat quality, meat freshness, rapid detection

Dynamic development of biosensors expands the possibilities of their application. Their usefulness has been shown in medicine, veterinary medicine, microbiology, food production and evaluation of food quality, environmental protection, military, protection from bio-terror, and forensic medicine (Otles and Yalcin, 2016).

The first biosensor was developed and built by Clark and Lyons, who utilised a platinum oxygen electrode and glucose oxidase enzyme for detection in a glucose solution. A change in the current intensity caused by a chemical reaction was proportional to the glucose content in the solution (Clark and Lyons, 1962). The first biosensor which found a practical and popular application, YSI Model 23A, was developed by Springs Instrument Company (USA) in 1975 and was intended for 
the determination of glucose concentration. The implementation of the innovative analytical method took 10 years, as the first widely available biosensor for glucose determinations appeared on the market not before 1987. In 1997, the International Union of Pure and Applied Chemistry (IUPAC) provided a definition of the biosensor, 'Device that uses specific biochemical reactions mediated by isolated enzymes, immunosystems, tissues, organelles or whole cells to detect chemical compounds usually by electrical, thermal or optical signal'.

The biosensor technology offers unlimited possibilities for its application in animal breeding, plant cultivation, food processing, as well as in food trade. The application of biosensors ensures a rapid, simple and inexpensive obtainment of reliable data on the quality. For example, it allows detecting flawed meat at various stages of production and storage. The oldest generation, i.e. enzymatic biosensors, still finds the broad practical application. Basic advantages of these devices consist in high sensitivity and specificity (Rana et al., 2010). Main flaws of this group of biosensors include a relatively short time of enzymatic stability and a necessity of periodical calibration (Ferreira et al., 2003). Repeatability, reproducibility, stability, and recovery are crucial traits of the biosensor.

New generations of biosensors are devices with broad potential, characterised by an increased sensitivity and precision, shortened test duration, simplicity of use, and relatively low price. Over the years, nanotechnology has revolutionized the field of biosensors (Chauhan et al., 2019). The advantages of nanomaterials, including high surface area with many active sites with excellent biocompatibility, ensure their wide bioanalytical applications (Chen et al., 2020). Various types of nanoparticles ranging from metal to carbon-based materials such as carbon nanotubes, graphite and graphene have been developed and are widely used in biosensors (Sharifi et al., 2020). In the future, nanobiosensors may play a vital role in the detection of microorganisms, pesticides, toxins, and other harmful chemicals in edible food.

In spite of their numerous advantages, the biosensors are not commonly used. They are still regarded as complementary tools for the conventional analytical methods, and they are used mainly in screening tests. Information on the application of biosensors in various branches of food industry, e.g. dairy industry, may be found in the literature. However, there is only scarce data pertaining to the application of biosensors in meat industry, despite their potentially large capabilities.

\section{Biosensors application}

\section{Evaluation of meat quality}

Considering different attributes, meat quality can be grouped according to the following five categories: sensory quality, technological quality, nutritional quality, product safety and ethical consideration. Biosensors found applications in three classes of meat quality evaluation such as sensory quality of raw meat (visual texture, color, visible fat, natural drip) as well as heated meat (aroma, flavor, texture), technological quality (water holding capacity, $\mathrm{pH}$ value, protein, lipid and connective tissue properties) and product safety (microbiological quality, food impurities including pesticides, heavy metal ions, antibiotics, hormones). 
Analytical targets for the biosensor application associated with the quality and safety of meat products can be classified in four categories: microbiological and other food impurities, meat freshness, meat tenderness and quality traits associated with glycolytic potential (Table 1).

Table 1. Biosensors in the evaluation of meat quality

\begin{tabular}{|c|c|c|c|c|}
\hline Sample & $\begin{array}{l}\text { Biosensor and } \\
\text { sample }\end{array}$ & Relationship & Traits & References \\
\hline 1 & 2 & 3 & 4 & 5 \\
\hline Hypoxanthine & $\begin{array}{l}\text { Amperometric/ } \\
\text { pork meat }\end{array}$ & $\begin{array}{l}\text { Correlation with } \\
\text { HPLC } \\
\mathrm{R}^{2}=0.906-0.926\end{array}$ & $\begin{array}{l}\text { Freshness, evalu- } \\
\text { ation of the ripen- } \\
\text { ing process }\end{array}$ & $\begin{array}{l}\text { Hernández- } \\
\text { Cázares et al., } \\
2010\end{array}$ \\
\hline Hypoxanthine & $\begin{array}{l}\text { Amperometric } \\
(\mathrm{TiO} 2-\mathrm{G}) / \text { pork } \\
\text { meat }\end{array}$ & $\begin{array}{l}\text { Correlation with } \\
\text { the conventional } \\
\text { enzymatic method } \\
(\mathrm{r}=0.9795) .\end{array}$ & Freshness & $\begin{array}{l}\text { Albelda et al., } \\
2016\end{array}$ \\
\hline $\begin{array}{l}\text { Hypoxanthine and } \\
\text { putrescine }\end{array}$ & $\begin{array}{l}\text { Amperometric } \\
\mathrm{Ag} / \mathrm{AgCl} \text { and } \\
\mathrm{Pl} / \text { beef meat }\end{array}$ & - & $\begin{array}{l}\text { Evaluation of } \\
\text { ripening process } \\
\text { and spoilage }\end{array}$ & $\begin{array}{l}\text { Yano et al., } \\
1995\end{array}$ \\
\hline Calpastatin & $\begin{array}{l}\text { Optical (SPR)/ } \\
\text { beef meat }\end{array}$ & $\begin{array}{l}\text { Correlation with } \\
\text { the conventional } \\
\text { enzymatic method } r= \\
(0.50-0.99)\end{array}$ & Tenderness & $\begin{array}{l}\text { Geesink et al., } \\
2005\end{array}$ \\
\hline Calpastatin & $\begin{array}{l}\text { Fluorescence } \\
(\text { FRET)/beef } \\
\text { meat }\end{array}$ & $\begin{array}{l}\text { Correlation with } \\
\text { WBSF } r=0.597 \text { modi- } \\
\text { fied } \mathrm{R}^{2}=0.6058 \text {. }\end{array}$ & Tenderness & $\begin{array}{l}\text { Van Eenennaam } \\
\text { et al., } 2007\end{array}$ \\
\hline Calpastatin & $\begin{array}{l}\text { Amperometric } \\
\text { (Tendercheck)/ } \\
\text { beef meat }\end{array}$ & $\mathrm{R}^{2}=0.62$ & Tenderness & Zór et al., 2011 \\
\hline Glucose & $\begin{array}{l}\text { Strip test/beef } \\
\text { meat }\end{array}$ & - & $\begin{array}{l}\text { Detection of meat } \\
\text { with a high } \mathrm{pH}\end{array}$ & $\begin{array}{l}\text { Pauly et al., } \\
2009\end{array}$ \\
\hline Glucose & $\begin{array}{l}\text { Strip test/beef } \\
\text { meat extract }\end{array}$ & $\begin{array}{l}\text { Correlation with Bon- } \\
\text { gault titration method } \\
\text { (ns) }\end{array}$ & $\begin{array}{l}\text { Evaluation of } \\
\text { glucose }\end{array}$ & $\begin{array}{l}\text { Hargreaves et } \\
\text { al., } 2009 .\end{array}$ \\
\hline Glucose & $\begin{array}{l}\text { Strip test/swine } \\
\text { blood obtained } \\
\text { during bleeding }\end{array}$ & $\begin{array}{l}\text { Negative correlation } \\
\text { with } \mathrm{pH}_{45} \text { of meat, } \\
\text { positive correlation } \\
\text { with the lightness of } \\
\text { meat }\end{array}$ & $\begin{array}{l}\text { Evaluation of } \\
\mathrm{pH}_{45} \text {, and lightness } \\
\text { of meat }\end{array}$ & $\begin{array}{l}\text { Choe et al., } \\
2009\end{array}$ \\
\hline Glucose, lactic acid & $\begin{array}{l}\text { Strip test/swine } \\
\text { blood obtained } \\
\text { during bleeding }\end{array}$ & $\begin{array}{l}\text { Comparison with } \\
\text { residual glycogen } \\
\text { contents and } \mathrm{pH}_{45}\end{array}$ & $\begin{array}{l}\text { Detection of meat } \\
\text { with pale colour } \\
\text { and an increased } \\
\text { waterness }\end{array}$ & $\begin{array}{l}\text { Choe et al., } \\
2015 \text { b }\end{array}$ \\
\hline Glucose, lactic acid & $\begin{array}{l}\text { Strip test/pork } \\
\text { meat-drip loss }\end{array}$ & $\begin{array}{l}\text { Correlation with the } \\
\text { residual glycogen } \\
(\mathrm{r}=0.84) \text { and with the } \\
\text { glycolytic potential } \\
(\mathrm{r}=0.79)\end{array}$ & $\begin{array}{l}\text { Estimation of } \\
\text { residual glycogen } \\
\text { and glycolytic } \\
\text { potential }\end{array}$ & $\begin{array}{l}\text { Park and Kim, } \\
\text { 2006; Young et } \\
\text { al., } 2004\end{array}$ \\
\hline
\end{tabular}


Table 1 - contd.

\begin{tabular}{l|l|l|l|l}
\hline 1 & \multicolumn{1}{c|}{2} & \multicolumn{1}{c}{3} & \multicolumn{1}{c}{4} & \multicolumn{1}{c}{5} \\
\hline Glucose & $\begin{array}{l}\text { Pork meat-drip } \\
\text { loss }\end{array}$ & $\begin{array}{l}\text { Glycolytic } \\
\text { potential }\end{array}$ & $\begin{array}{l}\text { Detection of pork } \\
\text { with reduced } \\
\text { quality }\end{array}$ & $\begin{array}{l}\text { Ferguson et al., } \\
2005\end{array}$ \\
Glucose & $\begin{array}{l}\text { Strip test/pork } \\
\text { meat-drip loss }\end{array}$ & $\begin{array}{l}\text { Correlation with } \\
\text { HPLC } \\
\text { r=0.937 }\end{array}$ & $\begin{array}{l}\text { Glucose content in } \\
\text { drip loss }\end{array}$ & $\begin{array}{l}\text { McGrath et al., } \\
2005\end{array}$ \\
\hline
\end{tabular}

Abbreviations: HPLC - high-performance liquid chromatography method; SPR - surface plasmon resonance, FRET - fluorescence resonance energy transfer; WBSF - Warner-Bratzler shear force.

Glycogen content has been identified as an important factor affecting meat quality. However, the evaluation of glycogen content in muscle in vivo and postmortem is difficult. A number of studies were performed to assess the impact of glucose and glycogen concentration on meat quality. In recent years, biosensors have been introduced for measurement of glucose and lactic acid to assess metabolic changes in muscle and meat (Choe et al., 2009; Choi et al., 2007; Przybylski et al., 2009; Przybylski et al., 2016; Young et al., 2004).

Glycogen is the main energy source of anaerobic metabolism of muscles, whereas glycogen content is an important factor regarding both consumer quality and technological quality of meat. The evaluation of glycogen content in muscles in vivo and after slaughter is complicated and time-consuming. In 1985, Monin and Sellier introduced the notion of glycolytic potential (GP) for the evaluation of glycogen content in muscles. The glycolytic potential is a sum of all glycogen metabolites, from which lactic acid forms after slaughter. The glycolytic potential is an important factor affecting the meat quality, which reflects the post-slaughter energy resources and biochemical changes occurring in muscles (Przybylski et al., 1994; Zybert et al., 2013).

The glucose level in muscles is an important factor reflecting the rate and extent of the post-slaughter glycolysis. A series of studies evaluating the influence of glucose and glycogen on the meat quality have already been carried out so far (Choe et al., 2009; Choi et al., 2007; Fernandez and Tornberg, 1991; Przybylski et al., 2009). Young et al. (2004) introduced a strip method for the evaluation of glucose level with cattle in the Longissimus dorsi (LD) muscle. The authors suggest that this method is suitable for common use in abattoirs and is particularly useful for the detection of meat with a high $\mathrm{pH}$. Hargreaves et al. (2009) successfully used household glucometers for the evaluation of glucose content in a beef meat extract. The authors compared their results with assays carried out by traditional titration (Bongault titration method) and found no statistically significant differences between the tests. The determination of glucose using strip tests also found application in pork meat. The strip test for glucose measurement is simple, fast, repeatable and inexpensive. The cost of glucose strip test for glycolytic potential assessment is ten times lower in comparison to the conventional method. It is possible to carry out multiple assays in series, contributing into a better knowledge on dynamic metabolic processes occurring in the meat after slaughter. 
Choe et al. (2009) determined glucose by strip tests, in blood samples obtained during bleeding, and they proved a negative correlation between the glucose level and $\mathrm{pH}$ of meat 45 minutes after slaughter $\left(\mathrm{pH}_{45}\right)$ and a positive correlation between the glucose content in the meat drip and the lightness of meat. Additionally, a relationship between the glucose level in blood from the filter-paper fluid uptake (FFU) and the solubility of sarcoplasm proteins and myofibril proteins was shown.

In their next studies, Choe et al. (2015 a, 2015 b) used biosensors for an investigation of glucose and lactates levels in blood obtained during bleeding. The researchers found that in case of pigs having an increased level of glucose, lactates and cortisol, 45 minutes after slaughter the residual glycogen content in the meat was reduced, while lactates level was elevated. The meat had a reduced $\mathrm{pH}$, it was characterised by a pale colour and an increased wateriness (Choe et al., 2015 b). It reflects intense early glycolytic processes, which may be caused by environmental factors, such as, e.g. the pre-slaughter stress. The authors point out the usefulness of glucose assays with biosensors in detection of pork with reduced quality. Hamilton et al. (2003) found that glucose level in the natural drip from the LD muscle is more strongly connected with the quality of fresh pork than the glycolytic potential.

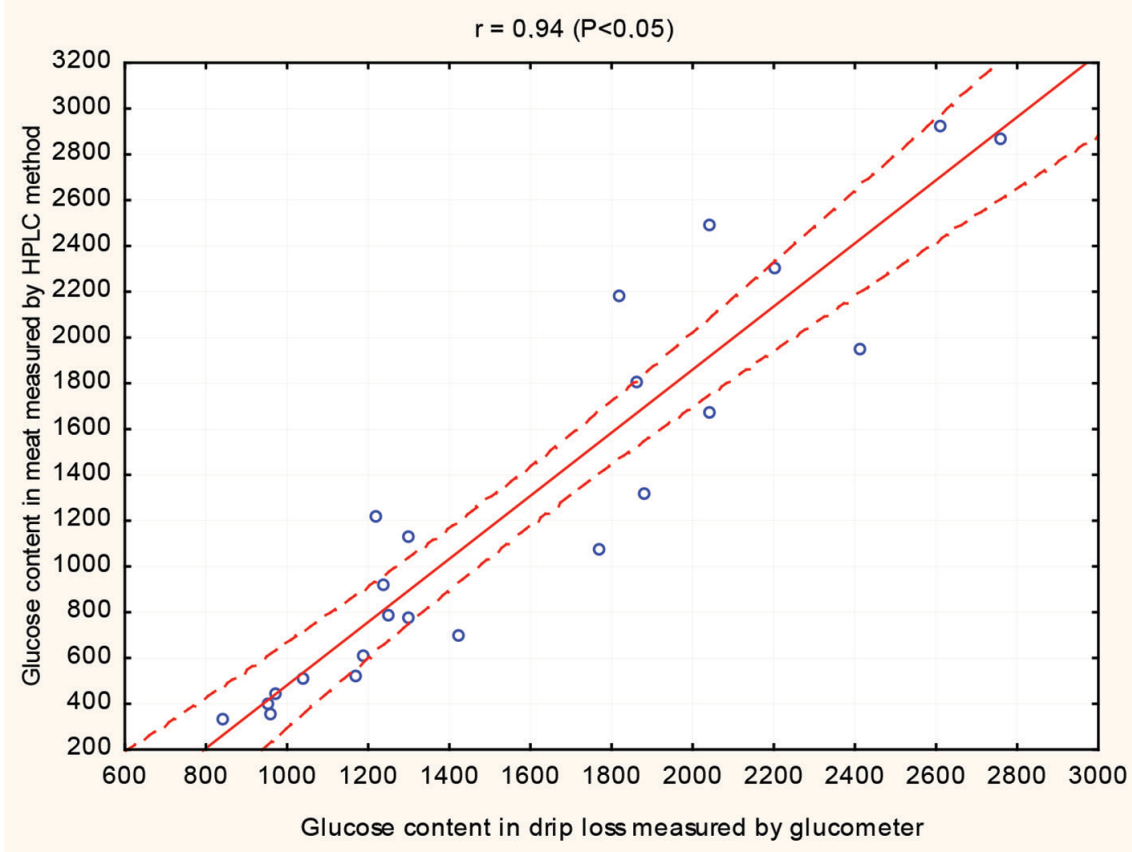

Figure 1. Correlation between glucose measured by biosensor strip test in the drip loss of pork meat and HPLC method (Buła, 2019)

Przybylski et al. (2016) proved usefulness of strip biosensors for determination of glucose and lactic acid contents in pork meat. The determination of muscle glucose was made with the Accu-Check Active ${ }^{\circledR}$ glucometer that is used for measuring blood glucose in humans and lactic acid (mmol.l) was measured with the strip 
method using Accutrend ${ }^{\circledR}$ Lactate type 3012522. The measurements were carried out in the meat drip loss (muscle juice) obtained after slaughter. Correlations between the glucose level in the natural drip loss measured by strip test and the residual glycogen $(\mathrm{r}=0.84)$, and between glucose and the glycolytic potential $(\mathrm{r}=0.79)$ were proved. Moreover, the glucose and lactates levels in the natural drip loss were positively mutually correlated. The authors concluded that use of biosensors can be a practical, simple and rapid method to predict muscle glycolytic potential (Przybylski et al., 2016).

The accuracy of measurements of glucose in drip loss with household glucometer is high, which is confirmed by the results of the study performed by Buła (2019). The correlation between glucose measured by biosensor strip test and HPLC was in good agreement $(\mathrm{r}=0.94)$ (Figure 1$)$. The measurements of glucose originating from muscles, e.g. in the drip, may constitute a good indicator of the muscle glycogen content.

\section{Biosensors in evaluation of microbiological contaminants in meat products}

The presence of pathogenic microorganisms in food, irrespective of their source, poses a threat to the health of consumers, and it may also pose an environmental hazard. Introduction of biosensors significantly expands the possibilities to monitor the food safety (Johnson et al., 2019). Biosensors offer high sensitivity and specificity, the assessment is easy and rapid. Regardless of the biosensors availability the traditional analytical methods i.e. bacterial colony count are still commonly used. They require equipped laboratories and involvement of highly-skilled personnel. One of the limitations is time-consuming sample preparation. Well-established microbiological methods are based on enrichment, filtration, incubation steps and the results are available within 2 to 10 days (Zhao et al., 2014). Novel methods based on biosensors offer improvement of rapidity, sensitivity, specificity and suitability for in situ analysis. The detection limits for microorganisms, their toxins and metabolites emphasize the necessity to dispose of very sensitive analytical methods for pathogen detection in meat (Table 2).

Table 2. Meat and products thereof - limits for microorganisms and their toxins, metabolites. According to the European Union Regulations Microbiological Criteria for Foodstuffs (European Commisssion, 2005)

\begin{tabular}{|c|c|c|}
\hline Food category & Microorganisms & Limits \\
\hline 1 & 2 & 3 \\
\hline $\begin{array}{l}\text { Minced meat and meat preparations intended to be eaten } \\
\text { raw }\end{array}$ & Salmonella & Absence in $25 \mathrm{~g}$ \\
\hline $\begin{array}{l}\text { Minced meat and meat preparations made from poultry } \\
\text { meat intended to be eaten cooked }\end{array}$ & Salmonella & Absence in $25 \mathrm{~g}$ \\
\hline $\begin{array}{l}\text { Minced meat and meat preparations made from other spe- } \\
\text { cies than poultry intended to eaten cooked }\end{array}$ & Salmonella & Absence in $10 \mathrm{~g}$ \\
\hline Mechanically separated meat (MSM) & Salmonella & Absence in $10 \mathrm{~g}$ \\
\hline $\begin{array}{l}\text { Meat products intended to be eaten raw, excluding prod- } \\
\text { ucts where the manufacturing process or the composition } \\
\text { of the product will eliminate the Salmonella }\end{array}$ & Salmonella & Absence in $25 \mathrm{~g}$ \\
\hline
\end{tabular}


Table 2 - contd.

\begin{tabular}{|c|c|c|}
\hline 1 & 2 & 3 \\
\hline $\begin{array}{l}\text { Meat products made from poultry meat intended to be } \\
\text { eaten cooked }\end{array}$ & Salmonella & Absence in $25 \mathrm{~g}$ \\
\hline \multirow[t]{2}{*}{ Carcasses of cattle, sheep, goats and bones } & Aerobic colony count & $\begin{array}{l}5.0 \log \mathrm{CFU} / \mathrm{cm}^{2} \\
\text { daily mean } \log \end{array}$ \\
\hline & Enterobacteriaceae & $\begin{array}{l}2.5 \log \mathrm{CFU} / \mathrm{cm}^{2} \\
\text { daily mean } \log \end{array}$ \\
\hline \multirow[t]{2}{*}{ Carcasses of pigs } & Aerobic colony count & $\begin{array}{l}5.0 \log \mathrm{CFU} / \mathrm{cm}^{2} \\
\text { daily mean } \log \end{array}$ \\
\hline & Enterobacteriaceae & $\begin{array}{l}3.0 \log \mathrm{CFU} / \mathrm{cm}^{2} \\
\text { daily mean } \log \end{array}$ \\
\hline Carcasses of cattle, sheep, goats and bones & Salmonella & Absence \\
\hline Carcasses of pigs & Salmonella & Absence \\
\hline Poultry carcasses of broilers and turkeys & Salmonella & Absence in $25 \mathrm{~g}$ \\
\hline \multirow[t]{2}{*}{ Minced meat } & Aerobic colony count & $5 \times 106 \mathrm{CFU} / \mathrm{g}$ \\
\hline & E.coli & $500 \mathrm{CFU} / \mathrm{g}$ \\
\hline \multirow[t]{2}{*}{ Mechanically separated meat (MSM) } & Aerobic colony count & $5 \times 106 \mathrm{CFU} / \mathrm{g}$ \\
\hline & E.coli & $500 \mathrm{CFU} / \mathrm{g}$ \\
\hline Meat preparations & E.coli & $5000 \mathrm{CFU} / \mathrm{g}$ or $\mathrm{cm}^{2}$ \\
\hline
\end{tabular}

Recent approaches develop highly sensitive biosensors for pathogens including the use of nanomaterials such as carbon nanotubes or magnetic nanoparticles. Multi-walled carbon nanotubes (MWCNTs) have unique electrical and mechanical properties, high surface area, and are proven to promote electron transfer between electrochemically active compounds and electrodes (Sun et al., 2012). Carbon nanotubes show greater potential for the detection of foodborne pathogens. Various biosensors were tested for detecting foodborne microorganisms (i. e. Escherichia coli, Listeria monocytogenes, Salmonella sp., Vibrio cholerae) and their toxins (Adley, 2014). They were proved to be valuable in the detection of colony below the level that can cause health hazard. Many biosensors have been developed for the detection of Escherichia coli bacterial strains, including the E. coli O157:H7 strain. Yamada et al. (2014) developed carbon nanotube-based junction biosensor for the detection of Escherichia coli. The detection limit of the developed sensor was $10^{2} \mathrm{CFU} / \mathrm{mL}$ with a detection time of less than 5 min (Yamada et al., 2014). In more recent research Luo and Alocilja (2017) presented a portable NMR-based biosensor for the detection $E$. coli $\mathrm{O} 157: \mathrm{H} 7$ strain in drinking water and milk samples. This device uses magnetic nanoparticles and microparticles as proximity sensors to amplify molecular interaction, it operates at 0.47 Tesla of magnetic strength. The bacteria are labeled with the magnetic nanoparticles through antibody-pathogen interaction. Its sensitivity is enhanced to $10^{1} \mathrm{CFU} / \mathrm{mL}$ - it is able to detect as low as $76 \mathrm{CFU} / \mathrm{mL}$ in water samples and as low as $92 \mathrm{CFU} / \mathrm{mL}$ in milk samples in about one minute (Luo and Alocilja, 2017). In the last decade, according to the Centers for Disease Control and Preven- 
tion (CDC) in the USA there were seven multistate outbreaks of Escherichia coli infections linked to beef. Overall, 184 people were infected, most of them required hospitalization. The result was a huge withdrawal of potentially infected beef from the market (Centers for Disease Control and Prevention, 2016).

The recently developed biosensor utilizes a built-in gyro sensor and the digital camera of a smartphone for reagentless microbial contamination of beef meat. The picture of meat surface taken with the smartphone is processed and analyzed by an implemented algorithm. The bacteria concentration is displayed on the smartphone screen. For the smartphone-based biosensor designed for detecting Escherichia coli $\mathrm{K} 12$ on beef products, the lower limits of detection were $10^{1} \mathrm{CFU} / \mathrm{mL}$ at angle $45^{\circ}$ and $10^{2} \mathrm{CFU} / \mathrm{mL}$ at angles $30^{\circ} \mathrm{C}$ and $60^{\circ} \mathrm{C}$. The result was comparable to the antibody-based microparticle Mie scatter assay. This smartphone-based biosensor is easy to use, inexpensive and it allows rapid and simple serial assessment of meat spoilage. This device can be used as a preliminary screening tool to monitor microbial contamination of meat products (Liang et al., 2014).

Salmonella spp. is one of the most important pathogens affecting food safety. Cinti et al. (2017) divided biosensors for Salmonella screening into four classes: electrochemical immunosensors, genosensors, aptasensors and phagosensors. One example is highly sensitive electrochemical immunosensor based on chitosan/gold nanoparticles composite covered with the specific anti-Salmonella antibody presented by Xiang et al. (2015). This biosensor provides a wide linear range from 10 to $10^{5}$ $\mathrm{CFU} / \mathrm{mL}$ with a low detection limit of $5 \mathrm{CFU} / \mathrm{mL}$, which indicates its potential in the clinical diagnosis of Salmonella contaminations.

Campylobacter jejuni is one of the most frequently occurring foodborne pathogens which can cause diarrhea and fever. The isolation of Campylobacter spp. is difficult as the bacteria are usually present in very few numbers. Morant-Miñana and Elizalde (2015) studied an electrochemical genosensor based on thin-film gold electrodes for the detection of Campylobacter jejuni in chicken meat samples. The good linear relationship was obtained for the concentrations of PCR method. Che et al. (2001) examined a fluorescence biosensor for the identification of Campylobacter jejuni in turkey and chicken meat. The detection limit of C. jejuni was $2.1 \times 10^{4} \mathrm{CFU} /$ $\mathrm{mL}$ indicating potential application in the poultry processing industry.

Shigella species of bacteria are responsible for severe foodborne or waterborne diarrhea in both developed and developing countries. Wang et al. (2016) developed a technique with multiple cross displacement amplification combined with a newly designed lateral flow biosensor and demonstrated high specificity and sensitivity for Shigella detection. The entire process, including specimen processing (35 min), amplification (20) and detection (2-5 min), can be finished within $1 \mathrm{~h}$. In another study the aptamer based fluorescent biosensor platform was tested for the detection of Shigella sonnei (Song et al., 2017). The designed platform showed a significant ability to detect and discriminate $S$. sonnei from other enteric species such as E. coli, Salmonella typhimurium and other Shigella species (S. flexneri, S. boydii).

Another foodborne pathogen is Listeria monocytogenes. The presence of this bacterium was in cut cured meat products, sausages (frankfurters), ripened cheese, fish and seafood. It causes listeriosis, which can be severe in some groups of patients. 
Particularly endangered consumer groups include people with lowered immunity, infants, seniors and pregnant women. The largest outbreak caused by food contaminated with the Listeria monocytogenes appeared in 2018 in South Africa with 943 laboratory confirmed cases of listeriosis and 174 deaths from the disease (Manganye et al., 2018). Optical biosensors effective in the detection of pathogenic strains of Listeria monocytogenes were developed. Mendonça et al. (2012) described the application of a highly specific fiber optic immunosensor coupled with an immunomagnetic separation for the detection of Listeria monocytogenes and Listeria ivanovii. The detection limit was $3 \times 10^{2} \mathrm{CFU} / \mathrm{mL}$ (Bhunia, 2012; Mendonça et al., 2012). Ohk et al. (2010) presented an antibody-aptamer functionalized fibre-optic biosensor for a specific detection of Listeria monocytogenes from artificially contaminated ready-to-eat meat products such as sliced beef, chicken and turkey after $18 \mathrm{~h}$ of enrichment. The aptamer-based biosensor distinguished pathogenic L. monocytogenes from nonpathogenic species or other pathogenic species such as E. coli or Salmonella. The detection limit was $10^{2}$ CFU $25 \mathrm{~g}^{-1}$ (Ohk et al., 2010).

Because of simultaneous occurrence of various pathogens in single food products, biosensors enabling detection of several pathogens are preferred. A biosensor developed by Wolter et al. (2008), containing three types of antibodies for the determination of E. coli O157:H7, Salmonella typhimurium and Legionella pneumophila in the sample being tested, constitutes an example of such a device (Wolter et al., 2008). The detection limits of the described readout system in water sample were $3 \times 10^{6}, 1 \times 10^{5}$, and $3 \times 10^{3}$ cells/mL for $S$. typhimurium, L. pneumophila, and E. coli O157:H7 and assay time was 13 min. Zhang et al. (2017) built multichannel surface plasmon resonance biosensor for a simultaneous detection of 3 important foodborne pathogens, Escherichia coli O157:H7 (O157:H7), Salmonella enteritidis, and Listeria monocytogenes, at a very low level in naturally contaminated food.

\section{Biosensors in assessment of meat contaminations}

Food quality encompasses the evaluation of meat products impurities like toxins, drug residues, heavy metals and pesticides. Well established, widely accepted methods, i.e. high performance liquid chromatography (HPLC), capillary electrophoresis and mass spectrometry for detecting food contaminations are time-consuming and costly. Biosensors offer a possibility of detecting and monitoring food contaminants. Rapid detection and adequate sensitivity are crucial to avoid consumers' health hazard. In order to determine the concentration of heavy metals such as arsenic, cadmium, mercury, and lead biosensors have been developed utilizing genetically modified microorganisms and enzymes such as urease, cholinesterase, glucose oxidase, alkaline phosphatase etc. (Narsaiah et al., 2012).

Another important issue is constituted by the detection of antibiotics in food. The problem of increasing resistance of microorganisms to antibiotics results from common use of the latter. Apart from therapeutic indications, antibiotics are administered by breeders in subtherapeutic doses in order to induce a mass increase in livestock (mainly fluoroquinolones and sulphonamides with a broad antibacterial spectrum against Gram-positive and Gram-negative bacteria) (FAO/WHO, 2011). Because of a large scale of this phenomenon, screening tests are of a particular importance. 
In 2010, the share of biosensors in the detection of antibiotics in food amounted to only $8 \%$ (Cháfer-Pericás et al., 2010). In the surface plasmon resonance (SPR) technique, the main element of the biosensor is constituted by an optical converter measuring the refractive index of polarised light rays absorbed by the tested substance. The obtained signal is expressed in the form of resonance units (RU), where $1 \mathrm{RU}$ corresponds to $1 \mathrm{pg} / \mathrm{mm}^{2}$ of the substance bonded to the receptor surface of the sensor. The substances being tested are bonded with the receptor layer based on the competitive or inhibitive mechanism. When residues of an antibiotic are present, the antibodies bond with the antibiotic, inhibiting bonding of the antibodies with the sensor, which results in a decrease in the RU value. When there is no antibiotic in the tested sample, the antibodies bind with the sensor antigens, and the RU value reaches a maximum (Mungroo and Neethirajan, 2014). The information about the biological activity of toxic substances including biotoxins can be obtained by cell-based sensors. These sensors, unlike other nucleic acid or antibody-based ones, respond to the toxins in a physiologically relevant manner, yielding information on the mechanism of action, and toxicological outcome of exposures.

Biosensors for the determination of aminoglycosides in pork, macrolides and lincosamides in poultry meat and pork, quinolones and tetracyclines in poultry meat and streptomycin in meat are available (Reder-Christ and Bendas, 2011; Mungroo and Neethirajan, 2014; Singh et al., 2016). Cai et al. (2019) synthesized a chemiluminescence sensor capable of recognizing 8 benzimidazoles (anthelmintic drugs commonly used broad-spectrum for the treatment of endoparasites in animals). The results as for beef and mutton samples showed that the sensor achieved ultrahigh sensitivity (limits of detection of $1.5-21 \mathrm{pg} / \mathrm{mL}$ ), rapid assay process (18 min) and satisfactory recovery $(65.8 \%-91.2 \%)$.

Some of the key biosensors that can detect toxins, drug residues, heavy metals and pesticides are presented in Table 3 .

Table 3. Examples of biosensors in assessment of meat contaminations

\begin{tabular}{|c|c|c|c|c|}
\hline Group & Biosensor/method & Substance/pathogen & Product & References \\
\hline 1 & 2 & 3 & 4 & 5 \\
\hline \multirow[t]{3}{*}{ Toxins } & $\begin{array}{l}\text { Suspension- } \\
\text { bead-array-based } \\
\text { optical biosensor/ } \\
\text { amperometry }\end{array}$ & $\begin{array}{l}\text { Botulinum neuroto- } \\
\text { xins type A and B, } \\
\text { staphylococcal ente- } \\
\text { rotoxin B }\end{array}$ & $\begin{array}{l}\text { Milk, baby food } \\
\text { and yoghurt }\end{array}$ & $\begin{array}{l}\text { Basavanna et al., } \\
\text { 2013; Pauly et al., } \\
2009\end{array}$ \\
\hline & $\begin{array}{l}\text { A multi-well plate- } \\
\text { based biosensor/ } \\
\text { Ped-2E9, }\end{array}$ & $\begin{array}{l}\text { Listeria-toxin listeri- } \\
\text { olysin } \mathrm{O} \text {, } \\
\text { Bacillus-enterotoxin }\end{array}$ & -* & $\begin{array}{l}\text { Banerjee et al., } \\
2008\end{array}$ \\
\hline & $\begin{array}{l}\text { Six-channel SPR } \\
\text { biosensor }\end{array}$ & Domoic acid & Pacific razor clams & $\begin{array}{l}\text { Stevens et al., } \\
2007\end{array}$ \\
\hline \multirow[t]{2}{*}{ Drug residues } & SPR & Chloramphenicol & $\begin{array}{l}\text { Pork, beef poultry, } \\
\text { milk, honey, } \\
\text { prawn }\end{array}$ & $\begin{array}{l}\text { Ferguson et al., } \\
\text { 2005; Park and } \\
\text { Kim, 2006; Gao } \\
\text { et al., } 2014\end{array}$ \\
\hline & SPR & 19 sulfonamides & Porcine muscle & $\begin{array}{l}\text { McGrath et al., } \\
2005\end{array}$ \\
\hline
\end{tabular}


Table 3 - contd.

\begin{tabular}{|c|c|c|c|c|}
\hline 1 & 2 & 3 & 4 & 5 \\
\hline & $\begin{array}{l}\text { Biosensor } \\
\text { immunoassay }\end{array}$ & Flumequine & $\begin{array}{l}\text { Broiler muscle } \\
\text { and serum }\end{array}$ & $\begin{array}{l}\text { Haasnoot et al., } \\
2007\end{array}$ \\
\hline & $\begin{array}{l}\text { EIS based } \\
\text { aptasensor } \\
\text { multiwall carbon } \\
\text { nanotubes }\end{array}$ & Tetracycline & Milk & $\begin{array}{l}\text { Chen et al., 2014; } \\
\text { Liu et al., 2016; } \\
\text { Zhou et al., } 2012\end{array}$ \\
\hline & $\begin{array}{l}\text { Chemilumines- } \\
\text { cence sensor }\end{array}$ & Benzimidazoles & Beef mutton & Cai et al., 2019 \\
\hline \multirow[t]{2}{*}{ Heavy metals } & $\begin{array}{l}\text { Fiber optic, } \\
\text { enzyme urease }\end{array}$ & Cadmium & Milk & Verma et al., 2010 \\
\hline & $\begin{array}{l}\text { Fluorescence- } \\
\text { based siderophore }\end{array}$ & Ferric ions & $-^{*}$ & Gupta et al., 2008 \\
\hline \multirow[t]{3}{*}{ Pesticides } & $\begin{array}{l}\text { Hybrid nano- } \\
\text { composite/ace- } \\
\text { tylcholinesterase } \\
\text { immobilisation }\end{array}$ & Pesticides & Water samples & $\begin{array}{l}\text { Chauhan et al., } \\
2016\end{array}$ \\
\hline & $\begin{array}{l}\text { Portable gold- } \\
\text { based nanobio- } \\
\text { sensor }\end{array}$ & Pesticides & -* & Kim et al., 2015 \\
\hline & $\begin{array}{l}\text { Acetylcholine es- } \\
\text { terase and choline } \\
\text { oxidase bienzyme } \\
\text { system. }\end{array}$ & Organophosphorus & -* & Lee et al., 2010 \\
\hline
\end{tabular}

Explanatory notes: SPR - surface plasmon resonance, EIS electrochemical impedance spectroscopy, _* - no data.

Due to the early detection of contaminants, pathogens, toxins etc. in food products immediate withdrawal of a suspicious product from the market is possible.

\section{Importance of biosensors in the evaluation of freshness of meat}

Meat freshness is generally associated with meat aging and spoilage (Dave and Ghaly, 2011). During a prolonged storage of meat, both monitoring meat ageing, and evaluation of meat spoilage are desired. Hypoxanthine - ATP degradation product is one of the most important markers of meat freshness. The concentration of hypoxanthine increases with storage days. Concentration of hypoxanthine in fresh pork is $0.19 \mu \mathrm{mol} / \mathrm{g}$ whereas in defective meat (PSE - pale, soft and exudative) it is $0.36 \mu \mathrm{mol} / \mathrm{g}$ (Aristoy and Toldrá, 2009). Hernández-Cázares et al. (2010) used an amperometric biosensor for the determination of hypoxanthine content in stored pork meat. The authors compared the results obtained using samples of an LD muscle with measurements carried out by the HPLC and found a high consistence of the results $\left(\mathrm{R}^{2}=0.906\right.$ and 0.926$)$. The researchers pointed out the biosensors as an inexpensive and simple tool useful for quality evaluation of stored meat. Albelda et al. (2016) published a paper describing application of a newly-developed amperometric graphene sensor with titanium dioxide $\left(\mathrm{TiO}_{2}-\mathrm{G}\right)$ for the evaluation of meat freshness. Hypoxanthine content in pork meat stored at room temperature for 7 days was determined. The results were compared with the conventional enzymatic method, and 
a correlation coefficient was obtained $(\mathrm{r}=0.9795)$. The hypoxanthine detection limit was $9.5 \mu \mathrm{M}$, and the sensitivity $4.1 \mathrm{nA} / \mu \mathrm{M}$. Introduction of the nanosensor technology in examination of food products, including meat products, opens wide possibilities of their practical application.

Spoilage markers are the substances such as biogenic amines (putrescine and cadaverine), trimethylamine, volatile amines and bacterial colony (Albelda et al., 2016). Cadaverine and putrescine are key indicators of meat spoilage. The usual content of putrescine in fresh beef and pork is low $<2 \mathrm{mg} . \mathrm{kg}_{-}{ }^{1}$. During storage biogenic amines content increases in relation to the microbial population of raw materials used and hygiene level of the manufacturing process (Kalač, 2006). Yano et al. (1995) proposed a simultaneous evaluation of the beef ripening process and its spoilage using a biosensor utilising $\mathrm{Ag} / \mathrm{AgCl}$ and platinum electrodes, immobilising hypoxanthine oxidase and putrescine oxidase. In order to obtain liquid samples, the meat was subjected to homogenisation and filtration. The results of putrescine determinations using the biosensor, in order to evaluate meat spoilage, were compared with assays carried out by the liquid chromatography method. The authors proved usefulness of the amperometric biosensor for the detection of biogenic amines and hypoxanthine in beef.

A group from the University of Groningen developed a novel biosensor for meat spoilage assessment, which for the first time utilises bacteria as a sensing component. Bacillus subtilis respond to volatiles released from spoiled meat (pork/cow minced meat). By using transcriptome analysis they identified promoters which efficiently drive fluorescent protein production in Bacillus subtilis (Daszczuk et al., 2014).

\section{Importance of biosensors in the evaluation of tenderness of meat}

Meat tenderness is one of the most important traits of meat quality for consumers. Assessment of calpain proteolytic system immediately after slaughter can predict the rate of tenderization and can serve as a tool for meat classification. Amperometric and optical biosensors developed for calpain evaluation are characterised with low detection limit and good sensitivity (Geesink et al., 2005; Zór et al., 2011).

The proteolytic processes occurring in meat after slaughter are under the control of more than one enzyme system (Hopkins and Thompson, 2001). A particular role is played by a group of enzymes - calpain and cathepsins. They affect the metabolism of proteins and regulate the tenderness of meat (Hopkins and Geesink, 2009). Calpastatin is an inhibitor of $\mu$-calpain affecting the tenderness of meat. It is estimated that genetic factors are responsible for $40 \%$ of the calpastatin system activity (Whipple et al., 1990; Shackelford et al., 1994; Gregula-Kania, 2012; Parra-Bracamonte et al., 2015). Despite the commercially available DNA assays serving the purpose of breeding selection, quality evaluation of meat and its classification are still of key importance (Greaser, 2009).

The conventional methods, i.e. ELISA, Western blot, chromatography ones are time-consuming and hardly practical, thus difficult to use on a broad scale (Whipple et al., 1990; Van Eenennaam et al., 2007). The biosensor technology offers new possibilities in this regard. Currently available biosensors detect the calpastatin antibodies in a homogenised meat sample. Geesink et al. (2005) applied an optical biosensor using 
the surface plasmon resonance (SPR) technique for the evaluation of calpastatin activity in beef meat samples. In a series of assays, in consecutive days of meat storage, a linear correlation with the conventional enzymatic method was demonstrated, with a correlation coefficient in the range of $r=0.50-0.99$. Bratcher et al. (2008 a) applied a new-generation optical biosensor in the evaluation of stored meat. The fluorescence resonance energy transfer (FRET) method for calpastatin determination was used in the device. In comparison with the conventional method for the evaluation of tenderness of meat - Warner-Bratzler shear force (WBSF) - the highest correlation coefficient was obtained in the 48th hour after slaughter and amounted to $r=0.597(\mathrm{P} \leq 0.01)$, and after its modification $-\mathrm{R}^{2}=0.6058$. According to the authors, the 48 th hour postmortem is the best time for classification of the meat quality using optical biosensors (Bratcher et al., 2008 b; Grant et al., 2005). Zór et al. (2011) used a multichannel amperometric portable sensor (Tendercheck system) for calpastatin determination in beef meat. The sensor was characterised by a similar correlation coefficient with the WBSF method $\left(\mathrm{R}^{2}=0.62\right)$. The developed system can be used for 7 days without a sensitivity loss or specificity loss (Zór et al., 2011).

\section{Conclusions}

The biosensor technology offers many possibilities for the evaluation of quality of meat and meat products. An effective control over every stage of the production processes ensures safety and quality of products offered to customers (Ferreira et al., 2003; Newman and Setford, 2006; Cock et al., 2009). The available biosensors enable the evaluation of freshness, the classification of tenderness of meat products, and the evaluation of the glycolysis extent (Balasubramanian et al., 2004; HernándezCázares et al., 2010; Daszczuk et al., 2014; Przybylski et al., 2016). Information obtained thanks to the biosensoric evaluation contributes to the development of breeding methods, the improvement of production processes and the development of new food products. Biosensors may be used in the evaluation of raw materials, as well as the individual production stages, including transport, storage and culinary treatment of the products. Despite various advantages of biosensors designed for meat quality assessment their widespread practical implementation remains limited. Additional studies should be performed to confirm good correlation of biosensors with standard methods. For meat quality and safety assessment the use of more stable bioreceptors with low detection limit and good sensitivity is preferred. It can be achieved by using newly developed materials e.g. nanomaterials. The ideal biosensor should be easy to use with satisfactory recovery time. The preparation of tested sample should be as simple as possible and not time consuming and the results should be available in about one minute, in a form transferable via computer or smartphone. The sensitivity and specificity should be comparable to standard laboratory methods. For instance, the results of glucose content in pork drip-loss obtained with strip tests showed a very high correlation $(\mathrm{r}=0.937$ in study of McGrath et al., 2005 and $\mathrm{r}=0.94$ in study of Buła, 2019) with HPLC. It seems that the cost of single test should not exceed one euro. An example of widely accepted biosensors, with great practical significance for diabetic patients, are commercially available strip tests for glucose assessment. Due to simplicity, low cost, and portability printed biosensor such as a strip test amena- 
ble for mass production and a smartphone-based biosensor are promising for wide practical use. Other significant solutions with great potential for practical applications are multiplex detection devices, which seem to be suitable for a screening test, especially in the field of food contaminants, where only a small number of samples is suspected.

\section{References}

A d l e y C. (2014). Past, present and future of sensors in food production. Foods, 3: 491-510.

A 1 b e 1 d a J.A.V., U z u n o g 1 u A., S a n t o s G.N.C., S t a n c i u L.A. (2016). Graphene-titanium dioxide nanocomposite based hypoxanthine sensor for assessment of meat freshness. Biosens. Bioelectron., 89: 518-524.

A r i s t o y M.C., To 1 d rá F. (2009). Nucleotides and its derived compounds. In: Handbook of Muscle Foods Analysis, Nollet L.M.L., Toldrá F. (eds). CRC Press Inc. Taylor \& Francis Group, USA, pp. 279-290.

Balasubramanian S., Panigrahi S., Logue C.M., Marchello M., Doetkott C., G u H., S h e r w o o d J., N o l a n L. (2004). Spoilage identification of beef using an electronic nose system. Transactions of the ASAE, 47: 1625-1633.

B a nerje e P., L en z D., R obin s on J.P., R i ckus J.L., B huni a A.K. (2008). A novel and simple cell-based detection system with a collagen-encapsulated B-lymphocyte cell line as a biosensor for rapid detection of pathogens and toxins. Lab. Investig., 88: 196-206.

B a savanna U., Muruvanda T., B rown E.W., Sharma S.K. (2013). Development of a cellbased functional assay for the detection of Clostridium botulinum neurotoxin types A and E. Int. J. Microbiol., http://dx.doi.org/10.1155/2013/593219.

B h u n i a A.K. (2012). Highly specific fiber optic immunosensor coupled with immunomagnetic separation for detection of low levels of Listeria monocytogenes and L. ivanovii. BMC Microbiol., 12: 275.

B ratcher C.L., Grant S.A., Vas s a 11 i J.T., L or en ze n C.L. (2008 a). Enhanced efficiency of a capillary-based biosensor over an optical fiber biosensor for detecting calpastatin. Biosens. Bioelectron., 2: 1674-1679.

B ratcher C.L., Grant S.A., Vas salli T., L ore nzen C.L. (2008 b). Enhanced efficiency of a capillary-based biosensor over an optical fiber biosensor for detecting calpastatin. Biosens. Bioelectron., 23: 429-1434.

B u ła M., Przybylski W., J a w or ska D., Kajak-S ie mas zko K. (2019). Formation of heterocyclic aromatic amines in relation to pork quality and heat treatment parameters. Food Chem., 276: 511-519.

Ca i He.X., Cui P.L., Liu J., Li Z.B., Jia B.J., Zhang T., Wang J.P., Yuan W.Z. (2019). Preparation of a chemiluminescence sensor for multi-detection of benzimidazoles in meat based on molecularly imprinted polymer. Food Chem., 280: 103-109.

Centers for Disease Control and Prevention (2016). Multistate Outbreak of Shiga toxin-producing Escherichia coli O157:H7 Infections Linked to Beef Products Produced by Adams Farm (Final Update); https://www.cdc.gov/ecoli/2016/o157h7-09-16/index.html

Ch a uh an N., N ar ang J., J a in U. (2016). Amperometric acetylcholinesterase biosensor for pesticides monitoring utilising iron oxide nanoparticles and poly (indole-5-carboxylic acid). J. Exp. Nanosci., 11: 111-122.

Ch a u h an N., J a in U., S o n i S. (2019). Sensors for food quality monitoring. In: Nanoscience for Sustainable Agriculture, Pudake R., Chauhan N., Kole C. (eds.).Springer Nature Switzerland AG 2019, Sensors for Food Quality, https://doi.org/10.1007/978-3-319-97852-9_23.

Cháfer-Peri cás C., M a qui e ir a Á., P u chades R. (2010). Fast screening methods to detect antibiotic residues in food samples. Trends Anal. Chem., 29: 1038-1049.

C he Y., L i Y., S l a vi k M. (2001). Detection of Campylobacter jejuni in poultry samples using an enzyme-linked immunoassay coupled with an enzyme electrode. Biosens. Bioelectron., 16: 791-797. 
Chen D., Ya o D., X i e C., L i u D. (2014). Development of an aptasensor for electrochemical detection of tetracycline. Food Control, 42: 109-115.

Chen Y., Qi an C., Li u C., Shen H., Wang Z., P ing J., Wu J., Chen H. (2020). Nucleic acid amplification free biosensors for pathogen detection. Biosens. and Bioelectron., 153: 112049.

Choe J.H., Choi Y.M., Le e S.H., Nam Y.J., Jung Y.C., Park H.C., Kim Y.Y., Kim B.C. (2009). The relation of blood glucose level to muscle fiber characteristics and pork quality traits. Meat Sci., 83: 62-67.

Choe J., Choi M., Ryu Y., Go G., Kim B.C. (2015 a). Estimation of pork quality traits using exsanguination blood and postmortem muscle metabolites. Asian-Australas. J. Anim. Sci., 28: 862.

Cho e J.H. Choi M.H., Ry u Y.C., Lim K-S., Lee E-A., Kang J-H., Hong K. C., Le e S.K., K i m Y.T., M o o n S.S., L e e K.W., R h e e M.S., K i m B.C. (2015 b). Correlations among various blood parameters at exsanguination and their relationships to pork quality traits. Anim. Prod. Sci., 55: 672-679.

C h o i Y.M., R y u Y.C., K i m B.C. (2007). Influence of myosin heavy and light chain isoforms on early postmortem glycolytic rate and pork quality. Meat Sci., 76: 281-288.

Cint i S., Volpe G., P i er marin i S., D eli b a to E., Palle s ch i G. (2017). Electrochemical biosensors for rapid detection of foodborne salmonella: A Critical Overview. Sensors (Basel), https:// www.ncbi.nlm.nih.gov/pmc/articles/PMC5579882/

C la rk L.C. Jr., Ly o n s C. (1962). Electrode systems for continuous monitoring in cardiovascular surgery. Ann. NY Acad. Sci., 102: 29-45.

C o c k L.S., A re n a s A.M.Z., A p o n te A.A. (2009). Use of enzymatic biosensors as quality indices: a synopsis of present and future trends in the food industry. Chil. J. Agr. Res., 69: 270-280.

Daszczuk A., Dessalegne Y., Drenth I., Hendriks E., Jo E., Lente T., Oldebesten A., Parrish J., Poljakova W, Purwanto A., Raaphorst R., Boonstra M., Heel A., Herber M., Meulen S., Siebring J., Robin A.R.A., Heinemann M.P., Kuipers O.P, Veening J.W. (2014). Bacillus subtilis biosensor engineered to assess meat spoilage. ACS Synth. Biol., 3: 999-1002.

D a v e D., G h a ly A. (2011). Meat spoilage mechanisms and preservation techniques: a critical review. Am. J. Agr. Biol. Sci., 6: 486-510.

European Commission (2005). Commission Regulation (EC) No 2073/2005 on microbiological criteria for foodstuffs. http://eur-lex.europa.eu/LexUriServ/LexUriServ.do?uri=OJ:L:2005:338:0001:0026: $\mathrm{EN}$

FAO/WHO (2011). Tackling Antibiotic Resistance from a Food Safety Perspective in Europe. www. euro.who.int/data/assets/pdf_file/0005/136454/e94889

F ergus on J., B axter A., Young P., Kennedy G., E1li ot t C., Weigel S., Gatermann R., A s hw in H., S te a d S., S h a r m a n M. (2005). Detection of chloramphenicol and chloramphenicol glucuronide residues in poultry muscle, honey, prawn and milk using a surface plasmon resonance biosensor and Qflex ${ }^{\circledR}$ kit chloramphenicol. Anal. Chim. Acta, 529: 109-113.

Fernandez X., Tornberg E. (1991). A review if causes of variation in muscle glycogen content and ultimate $\mathrm{pH}$ in pigs. J. Muscle Foods, 2: 209-235.

Ferreira S., De Souza M.B., Trierweiler J.O., Broxtermann O., Folly R.M., $\mathrm{H}$ it z m a n n B. (2003). Aspects concerning the use of biosensors for process control: experimental and simulation investigations. Comput. Chem. Eng., 27: 1165-1173.

Ga o F., Feng S., Chen Z., Li - Chan E.C., Grant E., Lu X. (2014). Detection and quantification of chloramphenicol in milk and honey using molecularly imprinted polymers: Canadian pennybased SERS nanobiosensor. J. Food Sci., 79: 2542-25499.

Ge es in k G.H., Van der Pale J.G.P., Kent P., Ve is e th E., He m k e G., K o o h m a rai e M. (2005). Quantification of calpastatin using an optical surface plasmon resonance biosensor. Meat Sci., 71: 537-541.

Grant S.A., Stringer R.C., Studer S., Lichlyte D., Lorenzen C.L. (2005). Viability of a FRET dual binding technique to detect calpastatin. Biosens. Bioelectron., 21: 438-444.

Gre a s e r M.L. (2009). Proteins. In: Handbook of Muscle Foods Analysis, Nollet L.M.L., Toldrá F. (eds). CRC Press Taylor \& Francis Group, USA, pp. 57-74.

Gregula-Kania M. (2012). Effect of calpastatin gene polymorphism on lamb growth and muscling. Ann. Anim. Sci., 12: 63-72. 
Gupt a V., S a haran K., K u m ar L., Gupta R., S a ha i V., M it t a l A. (2008). Spectrophotometric ferric ion biosensor from Pseudomonas fluorescens culture. Biotechnol. Bioeng., 100: 284-296.

H a a s n o ot W., G e r ç e k H., Ca z e mi er G., N i e l e n M.W. (2007). Biosensor immunoassay for flumequine in broiler serum and muscle. Anal. Chim. Acta, 586: 312-318.

Hamilt on D.N., Miller K.D., Elli M., M c Ke ith F.K., Wils o n E.R. (2003). Relationships between longissimus glycolytic potential and swine growth performance, carcass traits, and pork quality. J. Anim. Sci., 81: 2206-2212.

H a rgreaves A.B., B arra les L.V., B arrales D.Z., Rivero s J.L.F., P e ña I.R. (2009). Glycogen determination in bovine muscle: a proposal for rapid determination. Chil. J. Agr. Res., 69: $366-372$.

Hernánde z-Cá z a res A.S., A r i s to y M.C., Toldrá F. (2010). Hypoxanthine-based enzymatic sensor for determination of pork meat freshness. Food Chem., 123: 949-954.

H o p k i n s D.L., G e e s i n k G.H. (2009). Protein degradation post mortem and tenderization. In: Applied Muscle Biology and Meat Science, Du M., McCormick J. R. (eds). CRC Press Inc., Taylor \& Francis Group, USA. pp. 149-173.

H o p k in s D.L., Th o m p s on J.M. (2001). The relationship between tenderness, proteolysis, muscle contraction and dissociation of actomyosin. Meat Sci., 57: 1-12.

J ohn s on J., A t k in D., L e e K., S e 11 M., C h a n d r a S. (2019). Determining meat freshness using electrochemistry: Are we ready for the fast and furious? Meat Sci., 150: 40-46.

K a la č P. (2006). Biologically active polyamines in beef, pork and meat products: a review. Meat Sci., 73: $1-11$.

K i m B.S., K i m G.W., H e o N.S., K i m M.S., Yang K.S., L e e S.Y., P a r k T.J. (2015). Development of a portable biosensor system for pesticide detection on a metal chip surface integrated with wireless communication. Food Sci. Biotechnol., 24: 743-750.

L e e J.H., H a n Y.D., S ong S.Y., K i m T.D., Y o on H.C. (2010). Biosensor for organophosphorus pesticides based on the acetylcholine esterase inhibition mediated by choline oxidase bioelectrocatalysis. BioChip J., 4: 223-229.

L i a n g P.S., P a rk T.S., Y o o n J.Y. (2014). Rapid and reagentless detection of microbial contamination within meat utilizing a smartphone-based biosensor. Sci. Rep., 4: 1-7.

Liu X., Zheng S., Hu Y., Li Z., Lu o F., He Z. (2016). Electrochemical immunosensor based on the chitosan-magnetic nanoparticles for detection of tetracycline. Food Anal. Methods, 9: 2972-2978

L u o Y., A l o c i lj a E.C. (2017). Portable nuclear magnetic resonance biosensor and assay for a highly sensitive and rapid detection of foodborne bacteria in complex matrices. J. Biol. Eng., 11: 14.

Manganye P., Desa i B., Daka M., B is milla R. (2018). Listeriosis in the City of Johannesburg, South Africa. S. Afr. J. Public Health, 2: 55-58.

McGrath T., Baxter A., Ferguson J., Haughey S., Bjurling P. (2005). Multi sulfonamide screening in porcine muscle using a surface plasmon resonance biosensor. Anal. Chim. Acta, 529: 123-127.

Mendonça M., Conrad N.L., Conceição F., Moreira A.N., de Silva W.P., Alei x o J.A.G., B h un i a A.K. (2012). Highly specific fiber optic immunosensor coupled with immunomagnetic separation for detection of low levels of Listeria monocytogenes and L. ivanovii. BMC Microbiol., 12: 275.

Mon in G., S elli er P. (1985). Pork of low technological quality with a normal rate of muscle $\mathrm{pH}$ fall in the immediate post-mortem period: the case of the Hampshire breed. Meat Sci, 13: 49-63.

Morant-Miñana M.C., Elizalde J. (2015). Microscale electrodes integrated on COP for real sample Campylobacter spp. detection. Biosens. Bioelectron., 70: 491-497.

Mungroo N.A., Neethirajan N. (2014). Biosensors for the detection of antibiotics in poultry industry - a review. Biosensors, 4: 472-493.

N ars a i a h K., Jha S.N., B hardwaj R., Sharma R., K u ma r R. (2012). Optical biosensors for food quality and safety assurance - a review. J. Food Sci. Technol., 49: 383-406.

N e w m a n J.D., S e t f or d S.J. (2006). Enzymatic biosensors. Mol. Biotechnol., 32: 249-268.

O h k S.H., K o o O.K., S e n T., Y a m a m o t o C.M., B h un i a A.K. (2010). Antibody aptamer functionalized fibre-optic biosensor for specific detection of Listeria monocytogenes from food. J. Appl. Microbiol., 109: 808-817. 
Ot l e s S., Ya lc in B. (2016). Review on the application of nanobiosensors in food analysis. Acta Sci. Pol. Technol. Aliment., 11: 7-18.

P a r k I.S., K i m N. (2006). Development of a chemiluminescent immunosensor for chloramphenicol. Anal. Chim. Acta, 578: 19-24.

Parra-Bracamonte G.M., Martinez-Gonzalez J.C., Sifuentes-Rincon A.M., Moreno-Medina V.R., Ortega-Rivas E. (2015). Meat tenderness genetic polymorphisms occurrence and distribution in five Zebu breeds in Mexico. Electron. J. Biotechnol., 18: $365-367$.

Pauly D., Kirchner S., S to ermann B., S chreiber T., Ka lfus s S., S chade R, Zbin d e n R., Avond e M.A., D orner M.B., D orner B.G. (2009). Simultaneous quantification of five bacterial toxins and plant toxins from complex matrices using a multiplexed fluorescent magnetic suspension assay. Analyst, 134: 2028-2039.

Przyby ls k i W., Ven in P., M on in G. (1994). Relationship between glycolytic potential and ultimate $\mathrm{pH}$ in bovine, porcine and ovine muscles. J. Muscle Foods, 5: 245-255.

Przybylski W., Gromadzka-Ostrowska J., Olczak E., Jaworska D., Niemyjski S., Santé-Lhoutellier V. (2009). Analysis of variability of plasma leptin and lipids concentration in relations to glycolytic potential, intramuscular fat and meat quality in P76 pigs. J. Anim. Feed Sci., 18: 296-304.

Przy by ls k i W., S i o n e k B., J a w or s k a D., S a n t é - L h o u te 11 i e r V. (2016). The application of biosensors for drip loss analysis and glycolytic potential evaluation. Meat Sci., 117: 7-11.

Rana J.S., Jindal J., B eniwal V., Chhokar V. (2010). Utility biosensors for applications in agriculture - a review. J. Am. Sci., 6: 353-375.

Reder-Christ K., B endas G. (2011). Biosensor applications in the field of antibiotic researcha review of recent developments. Sensors, 11: 9450-9466.

Shackelfor S.D., Koohmaraie M., Cundiff L.V., Gregory K.E., Rohrer G.A., S a vel1 J.W. (1994). Heritabilities and phenotypic and genetic correlations for bovine postrigor calpastatin activity, intramuscular fat content, Warner-Bratzler shear force, retail product yield, and growth rate. J. Anim. Sci., 72: 857-863.

Sharifi S., Vahed S. Z., Ahmadian E., Dizaj S.M., Eftekhari A., Khalilov R., Ahmadi M., Hamidi-A s 1 E., Labib M. (2020). Detection of pathogenic bacteria via nanomaterials-modified aptasensors. Biosens. and Bioelectron., 150: 111933.

S ing h P.K., J a ir a th G., A h l a w at S.S., P a the r a A., S ing h P. (2016). Biosensor: an emerging safety tool for meat industry. J. Food Sci. Technol., 53:1759-1765.

S ong M.S., Sekhon SS, Shin W.R., K im H.C., A hn J.Y., K im Y.H. (2017). Detecting and discriminating Shigella sonnei using an aptamer-based fluorescent biosensor platform. Molecules, 22: 825 .

Stevens R.C., Soelberg S.D., Eberhart B.L., Spencer S., Wekelld J.C., Chinows k y T.M., Tra in e r V.L., F u r long C.E. (2007). Detection of the toxin domoic acid from clam extracts using a portable surface plasmon resonance biosensor. Harmful Algae, 6: 166-174.

S un X., C a o Y., Gong Z., Wang X., Z hang Y., G a o J. (2012). An amperometric immunosensor based on multi-walled carbon nanotubes-thionine-chitosan nanocomposite film for chlorpyrifos detection. Sensors, 12: 17247-17261.

Van Eenenna m A.L., Li J., Tha 11 man R.M., Qua a R.L., Dikeman M.E., Gill C.A., Franke D.E., Thom a s M.G. (2007). Validation of commercial DNA tests for quantitative beef quality traits. J. Anim. Sci., 85: 891-900.

Ver m a N., K u ma r S., K a u r H. (2010). Fiber optic biosensor for the detection of Cd in milk. Biosens. Bioelectron., 1:102.

Wang Y., Wa n g Y., X u J., Ye C. (2016). Development of multiple cross displacement amplification label-based gold nanoparticles lateral flow biosensor for detection of Shigella. Front. Microbiol., 7: 1834.

Whipple G., Koohmaraie M., Dikeman M.E., Crous e J.D. (1990). Predicting beef-longissimus tenderness from various biochemical and histological muscle traits. J. Anim. Sci., 68: 4193-4199.

Wo 1 t e r A., N i e s s ne r R., S e i d e 1 M. (2008). Detection of Escherichia coli O157: H7, Salmonella typhimurium and Legionella pneumophila in water using a flow-through chemiluminescence microarray readout system. Anal. Chem., 80: 5854-5863. 
X i ang C., Li R., A dhik ar i B., Sh e Z., Li Y. (2015). Sensitive electrochemical detection of Salmonella with chitosan-gold nanoparticles composite film. Talanta, 140: 122-127.

Ya m a d a K., K i m Ch., K i m J., Ch un g J., L e e H.L., J u n S. (2014). Single walled carbon nanotube-based junction biosensor for detection of Escherichia coli. PLOS One, 9: e105767. https:// journals.plos.org/plosone/article?id=10.1371/journal.pone.0105767

Yano Y., Kataho N., M in o W., N a k a mura T., A s a no Y. (1995). Evaluation of beef aging by determination of hypoxanthine and xanthine contents: application of a xanthine sensor. Food Chem., 52: 439-445.

Young O.A., We st J., Hart A.L., va n O t t e rd ij k F.F.H. (2004). A method for early determination of meat ultimate $\mathrm{pH}$. Meat Sci., 66: 493-498.

Zhang X., Tsuji S., Kitaoka H., Kobayashi H., Tamai M., Honjoh K., Miyamoto T. (2017). Simultaneous detection of Escherichia coli O157:H7, Salmonella enteritidis, and Listeria monocytogenes at a very low level using simultaneous enrichment broth and multichannel SPR Biosensor. J. Food Sci., 82: 2357-2363.

Z h a o X., L in C.W., Wan g J., O h D.H. (2014). Advances in rapid detection methods for foodborne pathogens. J. Microbiol. Biotechnol., 24: 297-312.

Zh o u L., Li D.J., G a i L., W an g J.P., Li Y.B. (2012). Electrochemical aptasensor for the detection of tetracycline with multi-walled carbon nanotubes amplification. Sensor. Actuators B: Chemical, 162: 201-208.

Zór K., Castellarnau M., Pascual D., Pich S., Plasencia C., Bardsley R., Nisto r M. (2011). Development and application of a bioelectrochemical detection system for meat tenderness prediction. Biosens. Bioelectron., 26: 4283-4288.

Zybert A., Sieczkowska H., Antosik K., Krzęcio-Nieczyporuk E., Adamc z y k G., K oć w in - P o d s i a d ł a M. (2016). Relationship between glycolytic potential and meat quality of Duroc pigs with consideration of carcass chilling system. Ann. Anim. Sci., 13: 645-654.

Received: 29 X 2019

Accepted: 18 V 2020 